\title{
MOTIVASI DAN DUKUNGAN KELUARGA DENGAN KEAKTIFAN MASYARAKAT MENGIKUTI PROGRAM POSBINDU PTM
}

\author{
Motivation and Family Support With Community Activities to Follow \\ The "Posbindu PTM"
}

\author{
Asih Media Yuniarti ${ }^{1}$, Arief Fardiansyah ${ }^{2}$, Salma Wulida Putri ${ }^{3}$ \\ ${ }^{1,2}$ Program Studi S1 Kesehatan Masyarakat Stikes Majapahit Mojokerto \\ ${ }^{3}$ Dinas Kesehatan Kota Mojokerto
}

\begin{abstract}
Alamat Korespondensi : Prodi Kesehatan Masyarakat Stikes Majapahit Mojokerto Jl. Raya Jabon Gayaman KM.02 Mojoanyar Mojokerto, Jawa Timur - Indonesia E-mail : art.media79@gmail.com
\end{abstract}

\begin{abstract}
ABSTRAK
Permasalahan PTM yang tinggi dan dampaknya besar membutuhkan upaya pengendalian faktor resiko PTM dengan kegiatan Posbindu PTM. Tujuan penelitian ini adalah menganalisis hubungan motivasi dan dukungan keluarga dengan keaktifan masyarakat dalam mengikuti program Posbindu PTM.

Design penelitian ini adalah Cross sectional. Populasi dalam penelitian ini sebanyak 136 orang, dan siambil dengan menggunakan teknik Simple Random Sampling sebanyak 57 sampel. Instrumen yang digunakan adalah kuesioner motivasi dan kuesioner dukungan keluarga.

Hasil penelitian hubungan motivasi dan dukungan keluarga dalam mengikuti program Posbindu PTM di UPT Puskesmas Jatirejo menunjukkan bahwa sebagian besar responden tidak aktif dalam mengikuti Posbindu PTM sebesar 45 orang (78.9\%). Data di analisis menggunkan ChiSquare Test dengan hasil $p$ value 0.00009 untuk motivasi dengan keaktifan, dan 0.00005 untuk dukungan keluarga dengan keaktifan masyarakat mengikuti program Posbindu PTM. P value < $\alpha$ : 0.05 artinya ada hubungan antara motivasi dan dukungan keluarga dengan keaktifan masyarakat dalam mengikuti program Posbindu PTM di UPT Puskesmas Jatirejo Kabupaten Mojokerto.

Kesimpulan dari penelitian ini adalah terdapat hubungan motivasi dan dukungan keluarga dengan keaktifan masyarakat dalam mengikuti Posbindu PTM di UPT Puskesmas Jatirejo. Pentingnya ikut kegiatan sosialisasi preventif dan promotif akan dapat mempengaruhi perilaku dan presepsi masyarakat dalam mengikuti program Posbindu PTM.
\end{abstract}

Kata kunci : motivasi, dukungan keluarga, keaktifan, PTM, posbindu

\section{ABSTRACT}

The problems of high PTM and high impact require efforts to control the risk factors of PTM with Posbindu PTM activities. This research aimed to analyze the correlation between motivation and family support toward the activation of society in following PTM Posbindu program.

Design of this research was cross sectional research. The population in this research was 136, and the samples were taken using the simple random sampling technique of 57 samples. The instruments of this research were motivational questionnaires and family support questionnaires.

The results of the research on the correlation of motivation and family support in following the PTM Posbindu program in the UPT Puskesmas Jatirejo indicated that most of the respondents were inactive in following the Posbindu PTM of 45 people (78.9\%). The data analysis of the research used a chi-square test with $p$ value (0.00009) for motivation, and (0.00005) for family support. Hence, among those variables can be concluded that there were a significant correlation between motivation and family support toward the activation of society in following the PTM Posbindu program in the UPT Puskesmas Jatirejo, Mojokerto.

The conclution of this reseach it was correlation between motivation and family support toward the activation of society in following PTM Posbindu program in following the PTM 
Posbindu program in the UPT Puskesmas Jatirejo. In addition, performing preventive and promotional socialization activities will be able to influence the behavior and perception of the community in following the Posbindu PTM program

Keywords : motivation, family support, activation, PTM, Posbindu

\section{PENDAHULUAN}

Transisi epidemiologi menandai adanya perubahan pola kejadian penyakit. Secara global, regional, dan nasional pada tahun 2030 transisi epidemiologi dari penyakit menular menjadi penyakit tidak menular semakin jelas. Perubahan pola penyakit tersebut sangat dipengaruhi antara lain oleh perubahan lingkugan, perilaku masyarakat, transisi demografi, teknologi, ekonomi, dan sosial budaya.

Secara nasional desa/kelurahan yang melaksanakan kegiatan posbindu PTM sebesar 43,9\%. Presentase ini sudah mencapai target Rencana Strategis Kementrian Kesehatan tahun 2018 yaitu sebesar 40\%. Pada tahun 2018 target 40\%, realisasi $43,9 \%$ atau sebanyak 35.749 desa/kelurahan yang melaksanakan posbindu PTM. Provinsi dengan desa/kelurahan yang melaksanakan Posbindu PTM terbanyak lainnya yaitu DKI Jakarta dan DI Yogyakarta sebesar 99,6\% dan 92,2\%. (Kemenkes RI, 2018).

Upaya pengendalian PTM dibangun berdasarkan komitmen bersama dari seluruh elemen masyarakat yang peduli terhadap ancaman PTM melalui posbindu PTM. Pengembangan posbindu PTM merupakan bagian integral dari system pelayanan kesehatan, diselenggarakan berdasarkan permasalahan PTM yang ada di masyarakat. Posbindu merupakan peran serta masyarakat dalam kegiatan deteksi dini dan pemantauan risiko PTM utama yang dilaksanakan secara terpadu, rutin, dan periodik.

\section{METODE}

Jenis penelitian ini adalah analitik kuantitatif dengan pendekatan cross sectional (Nursalam, 2016). Populasi dalam penelitian ini adalah masyarakat di Wilayah UPT Puskesmas Jatirejo yang mengikuti Posbindu PTM yang berjumlah 136 orang. Teknik sampling yang digunakan adalah random sampling. Untuk menguji hipotesis penelitian menggunakan uji korelasi sederhana Chi Square. Apabila hasil analisa penelitian didapatkan nilai $\mathrm{p} \leq 0,05, \mathrm{H}_{1}$ diterima yang artinya ada hubungan motivasi dan dukungan keluarga dengan keaktifan masyarakat dalam mengikuti Posbindu PTM.

Proses pengumpulan data dari penelitian ini yakni, setelah mendapatkan persetujuan dari institusi STIKes Majapahit Mojokerto, kemudian meminta surat persetujuan dari Bangkesbangpol Kabupaten Mojokerto, dilanjutkan ke Dinas Kesehatan Mojokerto, setelah itu meminta surat persetujuan dari lokasi penelitian yaitu UPT Puskesmas Jatirejo Mojokerto. Karena proses pengumpulan data dilakukan ditengah pandemi Covid-19 maka peneliti harus 
melakukan penelitian sesuai protokol kesehatan yang telah ditetapkan.

Prosedur pelaksanaan, subjek akan diberikan lembaran kuesioner terkait motivasi dan dukungan keluarga. Setelah prosedur pengisian kuesioner selesai dan data sudah terkumpul, peneliti akan melakukan pemeriksaan kelengkapan data yang diperoleh dari responden.

\section{HASIL DAN PEMBAHASAN}

Berikutnya akan disajikan hasil dari pengelolaan data penelitian:

\section{DATA UMUM Karakteristik Responden}

Tabel 1. Karakteristik Responden

\begin{tabular}{llcc}
\hline No. & Karakteristik & n & (\%) \\
& Responden & & \\
\hline 1. & Usia & & \\
& $21-35$ & 9 & 15,8 \\
& $36-50$ & 17 & 29,8 \\
& 51-69 & 31 & 54,4 \\
\hline 2. & Jenis Kelamin & & \\
& Laki-laki & 21 & 36,8 \\
& Perempuan & 36 & 63,2 \\
\hline 3. & Tingkat Pendidikan & \\
& SD & 9 & 15,8 \\
& SLTP & 17 & 29,8 \\
& SLTA & 26 & 45,6 \\
& Perguruan & 5 & 8,8 \\
& Tinggi & & \\
\hline 4. & Pekerjaan & & \\
& Wirausaha & 11 & 19,3 \\
& IRT & 24 & 42,1 \\
& Petani & 9 & 15,8 \\
& Swasta & 9 & 15,8 \\
& Lainnya & 4 & 7,0 \\
\hline & Jumlah & $\mathbf{5 7}$ & $\mathbf{1 0 0}$ \\
\hline
\end{tabular}

Tabel 1 menunjukkan bahwa lebih dari setengan (54.4\%) responden berusia 51-69 tahun, sebagian besar ( 63.2\%) kelamin perempuan, hampir $(45.6 \%)$ berpendidikan SLTA dengan pekerjaan sebagai IRT sebesar (42.1\%).

\section{DATA KHUSUS \\ 1. Motivasi Masyarakat Mengikuti Program Posbindu PTM di UPT Puskesmas Jatirejo Mojokerto}

Tabel 2. Motivasi Masyarakat Dalam Mengikuti Program Posbindu PTM Di UPT Puskesmas Jatirejo Mojokerto

\begin{tabular}{ccc}
\hline Motivasi & n & \% \\
\hline Rendah & 36 & 63,2 \\
Tingi & 21 & 36,8 \\
\hline Total & $\mathbf{5 7}$ & $\mathbf{1 0 0}$ \\
\hline
\end{tabular}

Tabel 2 memperlihatkan lebih dari setengah $(63.2 \%)$ responden memiliki motivasi yang rendah. Motivasi merupakan suatu proses dimana kebutuhan mendorong seseorang untuk melakukan suatu rangkaian kegiatan yang mengarah ketercapaiannya tujuan tertentu. Motivasi dapat diartikan sebagai alat penggerak yang ada di dalam setiap individu untuk mencapai sutau tujuan yang akan di capai. Motivasi merupakan faktor pendorong seseorang untuk tercapainya suatu aktifitas (Rangga, 2016).

Berdasarkan kuesioner yang terkumpul, sebagian responden memiliki motivasi yang rendah. Responden yang memiliki motivasi rendah karena tidak tahu manfaat cek kesehatan secara rutin. Pengetahuan merupakan salah satu faktor intrinsik yang mempengaruhi motivasi. Pengetahuan juga merupakan hasil tahu, dan ini terjadi setelah orang melakukan penginderaan terrhadap suatu objek tertentu (Notoadmodjo, 2012). 
1. Dukungan keluarga dalam mengikuti program Posbindu PTM di UPT Puskesmas Jatirejo Mojokerto

Tabel 3. Dukungan Keluarga Mengikuti Program Posbindu PTM Di UPT Puskesmas Jatirejo

\begin{tabular}{lcc}
\hline Dukungan Keluarga & n & $\mathbf{\%}$ \\
\hline Rendah & 40 & 70,2 \\
Tinggi & 17 & 29,8 \\
\hline Total & $\mathbf{5 7}$ & $\mathbf{1 0 0}$ \\
\hline
\end{tabular}

Tabel 3 memperlihatkan bahwa sebagian besar responden memiliki dukungan keluarga yang rendah yaitu sebanyak 40 orang (70.2\%). Hasil wawancara dengan responden mengenai dukungan keluarga, hasil dari pertanyaan sebagian responden memiliki dukungan keluarga yang kurang, hal ini dikarenakan keluarga sibuk dengan pekerjaannya, sehingga mereka tidak sempat mengantarkan anggota keluarganya untuk cek kesehatan.

Kurangnya partisipasi anggota keluarga yang mengahambat masyarakat dalam mengikuti program Posbindu PTM. Selain dukungan dari keluarga, faktor lain seperti dukungan teman sebaya juga sangat berpengaruh dalam keaktifan mengikuti program Posbindu PTM. Mereka cenderung memilih melakukan kegiatan sehari-hari dirumah daripada harus mengikuti program Posbindu PTM dikarenakan jarak rumah yang tidak dekat dan tidak ada anggota keluarganya yang dapat mengantar. Sehingga mereka memilih untuk periksa cek kesehatan ketika sudah merasakan sakit dan perlu melakukan cek kesehatan.

\section{Keaktifan Masyarakat Dalam Mengikuti Program Posbindu PTM Di UPT Puskesmas Jatirejo Mojokerto}

Tabel 4. Keaktifan Keluarga Mengikuti Program Posbindu PTM Di UPT Puskesmas Jatirejo

\begin{tabular}{|c|c|c|}
\hline Keaktifan & $\mathbf{n}$ & $\%$ \\
\hline Rendah & 45 & 78,9 \\
\hline Tinggi & 12 & 21,1 \\
\hline Total & 57 & 100 \\
\hline
\end{tabular}

sebagian besar responden tidak aktif dalam mengikuti program Posbindu PTM yaitu sebanyak 45 orang (78.9\%). Faktor yang berkaitan dengan keaktifan masyarakat yaitu motivasi dan dukungan keluarga. Faktor tersebut berdampak pada keaktifan masyarakat dalam mengikuti program Posbindu PTM. Masyarakat yang tidak aktif mengikuti Posbindu PTM dikarenakan mereka yang memiliki motivasi rendah dan dukungan dari keluarga juga rendah, sehingga masyarakat lebih banyak yang tidak aktif untuk cek kesehatan.

\section{Hubungan Motivasi Masyarakat dengan Keaktifan Masyarakat Mengikuti Program Posbindu PTM di UPT Puskesmas Jatirejo Mojokerto}

Tabel 5 menunjukkan bahwa responden yang memiliki motivasi rendah mengikuti Posbindu PTM hampir seluruhnya $(97,2 \%)$ tidak aktif mengikuti Posbindu PTM, namun masih didapati 10 responden $(47,6 \%)$ memiliki 
motivasi tinggi dan tidak aktif. Hasil analisis uji Chi-Square menunjukkan bahwa nilai $p$.value : $0.00009<\alpha 0.05$ artinya ada hubungan motivasi dengan keaktifan masyarakat dalam mengikuti program Posbindu PTM di UPT Puskesmas Jatirejo.

Tabel 5. Hubungan Motivasi dengan Keaktifan Masyarakat dalam Mengikuti Program Posbindu PTM di UPT Puskemas Jatirejo

\begin{tabular}{cccccccc}
\hline & \multicolumn{5}{c}{ Keaktifan } \\
\cline { 2 - 7 } Motivasi & \multicolumn{2}{c}{ Tidak } & \multicolumn{2}{c}{ Aktif } & \multicolumn{2}{c}{ Total } \\
\cline { 2 - 7 } & \multicolumn{2}{c}{ Aktif } & $\%$ & $\mathrm{n}$ & $\%$ & $\mathrm{n}$ & $\%$ \\
\cline { 2 - 7 } Rendah & 35 & 97,2 & 1 & 2,8 & & \\
Tinggi & 10 & 47,6 & 11 & 52,4 & & \\
\hline \multicolumn{4}{c}{$\boldsymbol{P}$ Value } & $: 0,00009$ & & \\
\hline
\end{tabular}

Responden yang memiliki motivasi tinggi dan tidak aktif mengikuti Posbindu PTM dari hasil wawancara hal ini dikarenakan jadwal kegiatan Posbindu bersamaan dengan pekerjaan yang tidak bisa ditinggalkan, sehingga mereka lebih memilih bekerja. Hasil wawancara masyarakat cenderung menjawab pertanyaan menurut presepsi mereka. Presepsi merupakan suatu kegiatan yang fleksibel, yang dapat menyesuaikan diri secara baik terhadap masukan yang berubah-ubah (Notoatmodjo, 2012). Dalam kehidupan sehari-hari tampak bahwa presepsi manusia mempunyai kemampuan menyesuaikan diri dengan baik terhadap lingkungan dan budayanya. Persepsi positif yang didapat masyarakat terhadap program Posbindu PTM, akan sangat menentukan kesanggupan mereka untuk terlibat dan berpartisipasi secara aktif dalam pelaksanaan program Posbindu PTM secara berkesinambungan.

\section{Hubungan Dukungan Keluarga dengan Keaktifan Masyarakat Mengikuti Program Posbindu PTM di UPT Puskesmas Jatirejo Mojokerto}

Tabel. 5. Hubungan dukungan keluarga dengan keaktifan masyarakat mengikuti program Posbindu di UPT Puskemas Jatirejo

\begin{tabular}{cccccccc}
\hline & \multicolumn{5}{c}{ Keaktifan } \\
\cline { 2 - 7 } $\begin{array}{c}\text { Dukungan } \\
\text { Keluarga }\end{array}$ & $\begin{array}{c}\text { Tidak } \\
\text { Aktif }\end{array}$ & \multicolumn{2}{c}{ Aktif } & \multicolumn{2}{c}{ Total } \\
\cline { 2 - 7 } & $\mathrm{n}$ & $\%$ & $\mathrm{n}$ & $\%$ & $\mathrm{n}$ & $\%$ \\
\cline { 2 - 7 } Rendah & 38 & 95,0 & 2 & 5,0 & 57 & 100 \\
Tinggi & 7 & 41,2 & 10 & 58,8 & & \\
\hline & \multicolumn{1}{c}{$\boldsymbol{P}$ Value $: 0,00009$}
\end{tabular}

Tabel 6 menunjukkan bahwa sebagian besar (95.0\%) responden yang dukungan keluarganya Rendah dan 7 (41.2\%) responden dengan dukungan keluarga tinggi tidak aktif mengikuti Posbindu PTM. Hasil uji korelasi menunjukkan $p$ value $0.00005<$ $\alpha: 0.05$ yang berarti ada hubungan dukungan keluarga dengan keaktifan masyarakat dalam mengikuti program Posbindu PTM di UPT Puskesmas Jatirejo.

Dukungan keluarga yang rendah disebabkan karena kurangnya pengetahuan 
dari anggota keluarga terhadap kegiatan Posbindu (Umayana, 2015). Beberapa responden yang memiliki dukungan keluarga tinggi dan tidak aktif mengikuti Posbindu PTM hal ini dikarenakan responden memilih untuk cek tensi, kadar gula darah, cek berat badan, dan lainnya di bidan desa dengan alasan lebih dekat. Sedangkan responden yang memiliki dukungan kelurga rendah dan aktif mengikuti Posbindu PTM dikarenakan responden memiliki motivasi diri yang tinggi untuk datang ke tempat Posbindu PTM sendiri tanpa harus diantar oleh keluarganya. Selain itu mereka memilih melakukan kegiatan dirumah daripada harus keluar mengikuti kegitaan lain diluar rumah, dan kurang komunikasi dengan anggota masyarakat, oleh karena itu tidak banyak masyarakat yang menjadi tidak ikut aktif dalam kegiatan Posbindu PTM.

Di masa pandemi Covid-19 sekarang mereka cenderung meminimalisir berkunjung ke pelayanan kesehatan termasuk kegiatan Posbindu PTM. Namun, untuk sekarang ketika sudah mulai digancarkan oleh pemerintah terkait "Kebiasaan New Normal", masyarakat sudah mulai banyak yang mengunjungi untuk cek kesehatan yang sempat tertunda sejak awal terjadi pandemi tersebut.

\section{PENUTUP}

Hasil penelitian menunjukkan ada hubungan antara motivasi dengan keaktifan (P Value: 0,00009) dan ada hubungan antara dukungan keluarga dengan keaktifan masyarakat ( $p$ value 0,00005) dalam mengikuti program Posbindu PTM di UPT Puskesmas Jatirejo Mojokerto. Kompleksitas permasalahan yang berhubungan dengan keaktifan masyarakat dibutuhkan pendekatan lebih dari masyarakat, keluarga terdekat, dan juga kader Posbindu, agar masyarakat lebih aktif dan memiliki motivasi tinggi dalam mengikuti kegiatan teresbut

\section{UCAPAN TERIMA KASIH}

Ucapan terima kasih kami berikan kepada 1) Kepala Dinas Kesehatan Kabupaten Mojokerto, 2) Kepala Puskesmas beserta Staf atas kesempatan, dan bimbingan dalam penelitian.

\section{DAFTAR PUSTAKA}

Kementerian Kesehatan Republik Indonesia. (2018). Riset Kesehatan Dasar Tahun 2018.

Notoatmodjo, Soekidjo. (2012). Promosi Kesehatan dan Perilaku Kesehatan. Jakarta: PT. Rineka Cipta.

Nursalam. (2016). Metodologi Penelitian Ilmu Keperawatan Edisi 3. Jakarta: Salemba Medika

Rangga; Naomi, Prima;. (2016). Pengaruh Motivasi Diri Terhadap Kinerja Belajar Mahasiswa. Jurnal Studi Kasus Pada Mahasiswa universitas Paramadina

Umayana; Try, Haniek; Cahyati, Widya Hary. (2015). Dukungan Keluarga Dan Tokoh Masyarakat Terhadap Keaktifan Penduduk Ke Posbindu Penyakit Tidak Menular. Jurnal kesehatan masyarakat, Nomor 1: 96-101 